Alexander Krisnayodi

130218099

Perekonomian Indonesia KP A

\title{
Enhancing the Tourism Sector in Indonesia to Compete in Southeast Asia
}

Tourism is the activities of people traveling to and staying in places outside their usual environment for leisure, business or other purposes for not more than one consecutive year. Tayibnapis and Sundari (2020) Tourism is very reliable because it has a very fast effect and has multiple impacts on the eyes of tourists. They not only see beautiful scenery, but also stay overnight, taste food and drinks, shop, and enjoy the activities provided by the locals. But the prestige of Bali until now still occupies the highest position and become the first tourist destination in Indonesia. In the framework of realizing Indonesia as a leading tourism destination, 6 programs have been launched: (1) developing leading destinations; (2) increasing competitiveness; (3) increasing tourism diversity; (4) increasing tourism integration; (5) strengthening as an Asian leading destination; and (6) strengthening as a world leading destination.

Tayibnapis and Sundari (2020) revealed that Indonesia's tourism sector continues to be encouraged to become one of the major foreign exchange earner sectors and has a direct impact on the people involved in tourism activities in the hope of covering current account deficits, increasing employment, and moving Micro, Small and Medium Enterprises (MSMEs). It should be understood that the tourism sector has direct and indirect impacts on the domestic economy. Indirectly the development of the tourism sector is able to absorb labor so that it has an impact on increasing economic growth. In addition, the tourism sector can directly increase capital flows to Indonesia. Indonesia has many attractive tourist destinations, such as Borobudur Temple, Mount Bromo, Lake Toba, Raja Ampat, Labuan Bajo, and others. The government of Indonesia tries to increase the number of overseas visitors through the exemption of visitor visas for 169 countries, accelerate the development of transportation infrastructure so that tourist destinations are accessible, and echo the image of Indonesian tourism Wonderful Indonesia.

Tayibnapis and Sundari (2020) also said that the contribution of tourism to the Gross Domestic Product (GDP) and foreign exchange supply for Indonesia is still lagging behind Singapore, Thailand and Malaysia due to the low competitiveness index, especially relating to the availability of information and communication technology, tourism service infrastructure, and health and hygiene issues. Other problems that also reduce competitiveness are institutional factors (especially in regions), security factors (prone to crime and dishonesty in transactions), and low awareness. Indonesia's desire to become a shopping paradise, as one part of the tourism industry, seems to be still difficult to realize due to the lack of support, for example the tax refund process that is still difficult for tourists, the small number of shops incorporated in tax returns, and the absence of factory outlets. 
Based on research by Tayibnapis and Sundari (2020) in addition, the Indonesian tourism sector actually also has several advantages over other countries, one of which is the price which is more competitive than in Singapore, Malaysia and Thailand. However, the main problem lies in the limited budget for promotion so that competitive prices and attractive offers are not well conveyed to foreign tourists. The tourism sector today and in the future is very much relied on to reduce the current account deficit. The tourism sector is targeted to contribute US \$ 17.6 billion in foreign exchange with the arrival of 18 million foreign tourists in 2019. However, until September 1, 2019, it only reached 9.31 million foreign tourists, even though Indonesia's tourism competitiveness rose two places to rank 40 . out of 140 countries in 2019 with a score of 4.3. The assessment score of 4.3 is based on environmental aspects, travel and tourism conditions, infrastructure, and natural and cultural resources. Indonesia's best value in competitiveness is in terms of price, and the lowest value in environmental sustainability.

Given that Indonesia has many abundant tourism resources, from relics of temples to stunning natural conditions. It has many tourism resources with high potential, but still fails to reach the tourist target every year. This fact can be concluded that the lack of development from various sectors is the cause of the failure of Indonesian tourism to achieve its targets. One of the efforts made by the government to maximize the role of Indonesian tourism is by improving infrastructure for easy access to tourists, as well as echoing Pesona Indonesia in the international arena to attract foreign tourists. It is hoped that Indonesian tourism can become one of the main sources of state revenue with the efforts of the government. Given the very large role of tourism in the domestic economy, where, directly or indirectly, tourism can significantly change the economic conditions of an area. Basically tourism market is formed because of the balance of demand and supply. There are many factors that affect the amount of demand and supply in the tourism market. Tourism demand is influenced by the amount of revenue, the effect of promotion, the price of airplane or ship tickets, the availability of infrastructure and facilities, the agenda of tourism security activities, and others. Meanwhile tourism supply is more influenced by the excellence and uniqueness of tourist destinations, hotels or lodging facilities, games, entertainment, souvenirs, and others.

The development of tourism in Indonesia is not only in infrastructure, but also in ecosystems in an effort to support the success of tourist destinations, such as aspects of culture, creativity, and hospitality so that people around the tourist destinations are not just spectators. Thus the development of tourism is expected to provide economic benefits, maintain the environment, and empower people in the real sense.

\section{Reference}

- Tayibnapis, A.Z. and Sundari, M.S. (2020). Boosting Indonesia's Tourism Sector to be Competitive. Indonesia: Surabaya Univesity. 